NBER WORKING PAPER SERIES

\title{
TRADE AND GROWTH IN EAST ASIAN \\ COUNTRIES: CAUSE AND EFFECT?
}

\author{
Jeffrey A. Frankel \\ David Romer \\ Teresa Cyrus
}

Working Paper 5732

\section{NATIONAL BUREAU OF ECONOMIC RESEARCH 1050 Massachusetts Avenue \\ Cambridge, MA 02138 \\ August 1996}

The authors would like to thank for support the Institute for International Economics in Washington, D.C., where Frankel was a Senior Fellow when much of this paper was written; the Export-Import Insurance Department of JETRO New York; the Center for International and Development Economics Research, funded at U.C. Berkeley by the Ford Foundation; and the Japan-United States Friendship Commission, a U.S. government agency. The authors would also like to thank Susanto Basu, Michael Dotsey, Brian Easton, Robert Hall, N. Gregory Mankiw, Glenn Rudebusch, James Stock, Shang-Jin Wei, and Richard Zeckhauser for comments on earlier drafts. This paper is part of NBER's research programs in International Finance and Macroeconomics, International Trade and Investment, and Economic Fluctuations and Growth. Any opinions expressed are those of the authors and not those of the National Bureau of Economic Research.

(C) 1996 by Jeffrey A. Frankel, David Romer and Teresa Cyrus. All rights reserved. Short sections of text, not to exceed two paragraphs, may be quoted without explicit permission provided that full credit, including $\mathbb{C}$ notice, is given to the source. 


\title{
TRADE AND GROWTH IN EAST ASIAN \\ COUNTRIES: CAUSE AND EFFECT?
}

\begin{abstract}
Estimates of growth equations have found a role for openness, particularly in explaining rapid growth among East Asian countries. But major concerns of simultaneous causality between growth and trade have been expressed. This study aims to deal with the endogeneity of trade by using as instrumental variables the exogenous determinants from the gravity model of bilateral trade, such as proximity to trading partners. We find that the effect of openness on growth is even stronger when we correct for the endogeneity of openness than in standard OLS estimates. We conclude with estimates of how much has been contributed to East Asian growth both by the exogenous or geographical component of openness and by the residual or policy component.
\end{abstract}

Jeffrey A. Frankel

Department of Economics

549 Evans Hall \#3880

University of California

Berkeley, CA 94720-3880

and NBER

jfrankel@iie.com

Teresa Cyrus

Department of Economics

549 Evans Hall \#3880

University of California

Berkeley, CA 94720-3880
David Romer

Department of Economics

549 Evans Hall \#3880

University of California

Berkeley, CA 94720-3880

and NBER

dromer@econ.berkeley.edu 
The record of rapid growth that many East Asian countries have attained over the last three decades is so spectacular that it has been claimed as supporting evidence by both sides in each of three debates (at least). First is the debate on whether the East Asians' success is proof of the superiority of protectionist policies on the one hand, or of outward-oriented policies on the other. Second is the broad debate whether the East Asian phenomenon is evidence of the virtues of government intervention in general, or of laissez-faire market-oriented policies. ${ }^{1}$ Third is the debate over whether the statistics support growth based on simple accumulation of the factors of production (labor, education, and especially physical capital), or growth based on improvements in technology and efficiency (measured as an increase in total factor productivity, or the "Solow residual"). ${ }^{2}$ Finally, in the latter case, there would also be the question whether this increase in technical efficiency was due (i) to superior government policies, in which case East Asia may have valuable lessons for other countries, (ii) to some superior mode of social organization, perhaps some exogenous aspect of Confucian culture, (iii) to simple catch-up with the technologically more advanced industrialized countries ${ }^{3}$, or (iv) to chance. ${ }^{4}$

1 Examples include Krueger (1990) vs. Pack and Westphal (1986), or the controversy surrounding World Bank (1993), including Rodrik (1994a). Laissez-faire is not the same as outward-orientation, of course, because some governments deliberately use subsidies or an undervalued currency to promote outward orientation.

2 Young (1992, 1994, 1994), Kim and Lau (1994), and Krugman (1994) have upset conventional wisdom by arguing that growth among the four East Asian dragons, especially Singapore, can be explained by simple factor accumulation, with no important residual left over in most cases. Sarel (1995) reviews the state of play.

${ }^{3}$ This is the famous convergence hypothesis: Barro (1991), Barro and Sala-i-Martin (1992), and Mankiw, Romer, and Weil (1992).

${ }^{4}$ Easterly (1995) and Easterly, Kremer, Pritchett, and Summers (1993). The main problem with the chance argument is that the East Asian success stories are all located in the same region. These authors point out that this ex post reasoning has some pitfalls. Nevertheless, this observed spatial correlation is a major motivation for the present paper. 
The subject of this paper is trade-led growth. In measuring trade, we lump together exports and imports. As emphasized by Grossman and Helpman (1991a,b) technological spillovers could come via imports as easily as exports.

Quite a few empirical studies of growth rates across countries find that the ratio of exports to GDP, or some other measure of openness, is a significant determinant of growth $^{5}$, and often that it is an important determinant for East Asian countries in particular. ${ }^{6}$ A typical specification begins with the standard determinants of GDP suggested by neoclassical growth theory, and adds a variable for exports as a share of GDP. For example, Feder (1982) regresses growth rates for 31 semi-industrialized countries over the period 1964-1973 against three variables: investment as a share of income, the rate of growth of the labor force, and the rate of growth of exports (times exports as a share of income). The coefficient on the last variable is highly significant statistically. Similarly, Edwards (1993, pp.9-11) regresses the rate of growth of total factor productivity on two measures of openness -- total trade as a percent of GDP and total tariff revenue as a per cent of trade -- along with some other variables, and finds that "in every regression the proxies for trade distortions and openness are highly significant."

${ }^{5}$ Examples include Michaely (1977), Krueger (1978), Feder (1982), Kohli and Singh (1989), Romer (1989), Quah and Rauch (1990), de Melo and Robinson (1991), DeLong and Summers (1991), Dollar (1992), Edwards (1993a), van den Berg and Schmidt (1994), Sachs and Warner (1995, p.35-37), Harrison (1995), and Eusufzai (1996). Edwards (1993b) and Rodrik (1993) survey the literature.

${ }^{6}$ Five examples are Helliwell (1.992, 1995), Page (1994), Pack and Page (1994), and Fukuda and Toya (1995). Pack and Page find that manufactured exports, in particular, are important in the growth equation, and that this variable explains part of the East Asian success (and that its coefficient is the same as for other parts of the world). Bradford (1994) surveys the literature. 


\section{The Problem of Simultaneity Between Trade and Growth}

Simultaneity is always a concern however. Rodrik (1994b, p.2), for example, argues that the standard view is "quite misleading on the importance it attaches to the role of exportorientation in the growth performance. It also has backward the causal relationship between exports, on the one hand, and investment and growth on the other." The mechanism of reverse causality that Rodrik has in mind runs as follows: an exogenous increase in investment in a developing country with a comparative disadvantage in producing capital goods, such as Korea, will necessitate an increase in imports of such goods (and in turn an increase in exports to pay for the imports). ${ }^{7}$ Similarly, Bradford and Chakwin (1993) argue that causality runs from investment to growth and exports, rather than the other way around. Helpman (1988, p.6) asks "Does growth drive trade, or is there a reverse link from trade to growth?" Harrison $(1995,9.26)$ concludes that "existing literature is still unresolved on the issue of causality."

Quite a few stories of reverse causality are possible. When the equation features a regression of GDP against exports (or the rates of change thereof), the simultaneity problem is clear: a correlation may emerge simply because exports are a component of GDP, rather than because of any extra contribution that trade makes to growth. In the case of imports, trade might rise with income because foreign goods are superior goods in consumption. Many studies have sought to identify some direct measures of trade policy, hoping that they are exogenous. ${ }^{8}$ But, aside from difficulties in measuring trade policies, which are typically serious enough, a

${ }^{7}$ Levine and Renelt (1992) reach similar conclusions.

a Ben-David (1993) focuses on the formation of the European Economic Community during the years 1959-1968 as an exogenous trade liberalization. 
fundamental conceptual problem of simultaneity remains (e.g., Sala-i-Martin, 1991). What if free-market trade policies are no more important to growth than free-market domestic policies, but tend to be correlated with them? Then openness will be observed to be correlated with growth, even though trade does not cause growth. A final possible mechanism is a pattern whereby poor countries tend to depend fiscally on tariff revenue, and to reduce tariffs as they become more developed.

A number of studies have tangled with the challenge posed by simultaneity. Jung and Marshall (1985), Hutchison and Singh (1987, 1992), and Bradford and Chakwin (1993) apply Granger-causality tests to the problem. Esfahani (1991) attempts a simultaneous equation approach. As so often in macro-econometrics, however, the simultaneity problem has remained largely intractable.

What is needed are good instrumental variables, which are truly exogenous, and yet are highly correlated with trade. This paper offers tests with such instruments: trade shares as predicted by the gravity model. The gravity model of bilateral trade, in its most basic form, says that trade between country $i$ and country $j$ is proportional to the product of $G P_{i}$ and GDP $\mathrm{G}_{j}$, and inversely related to the distance between them, by analogy to Newton's theory of gravitational attraction between two masses. Other explanatory variables often added include populations (or per capita GDPs), land areas, and dummy variables representing landlockedness, common borders, common languages, and common membership in regional trading arrangements. While the gravity model has long been' an ugly duckling of international economics -- obscure and allegedly lacking theoretical foundations -- it has recently enjoyed a swan-like revival. There are at least three reasons for that revival: its empirical success at predicting bilateral trade flows, improved 
theoretical foundations arising from modern theories of trade based on imperfect substitutes, and a new interest among economists in geography and trade that seeks to treat countries or regions as physically existing at particular locations in space rather than as disembodied constructs. ${ }^{9}$

Such variables as distances, populations, common borders, and common languages are as close to exogenous as we get in economics. From the viewpoint of a small individual country, the GDPs of trading partners are exogenous as well. ${ }^{10}$ Yet these variables are highly correlated with trade. Thus they make good instrumental variables. An intuitive way to implement the idea is to use the values predicted by the gravity model to instrument for the trade variable in the growth equation. If trade still appears to be a significant determinant of growth with this correction (taking care, of course, to use the right standard errors), then we can conclude that the effect is causal and not spurious.

In the latter case, we might also be able to go on and say something particularly interesting for the East Asian countries: to the extent that there is a Solow residual in the growth equation and it is associated with trade, how much of it can be explained by the proximity of the East Asian countries to trading partners with rapid factor accumulation? Is part of the growth residual explained by the trade share residual, i.e., to outward oriented policies, or to other

${ }^{9}$ The results of one early gravity study were reported in Linneman (1967). The theoretical rationale for the idea that bilateral trade depends on the product of GDPs comes from recent work by Helpman (1987) and Helpman and Krugman (1985, section 1.5). Frankel (1996) elaborates, applies the gravity model to issues of trade blocs tests for trade blocs, and gives further references. Frankel (1993) and Frankel and Wei (1994) focus on East Asian blocs.

${ }^{10}$ For a study like this one that seeks to explain growth for a cross-section of countries, one does not wish to treat GDPs of trading partners as exogenous, even if the domestic country is small. But if the standard factor-accumulation terms in a growth regression (labor force growth, investment, and education) can be treated as exogenous in the domestic country, then they can also be considered exogenous in trading partners, as discussed below. 
unknown factors, excluding proximity to rapidly growing trade partners? Or, on the other hand, to put it simply, is it just that they are lucky enough to be located near each other?

Somewhat relevant to this idea are tests in a number of recent papers. DeLong and Summers tested for spatial correlation of residuals in their growth regression, and (surprisedly and surprisingly) failed to find any correlation based on physical proximity. Chua (1993), on the other hand, finds "strong evidence for positive regional spillovers, accounting for about 14 to 18 per cent of a country's growth rate." Elliott (1994) finds spatial correlation in growth, as well as in the residuals from a standard growth regression, particularly among the East Asian countries. A correction for this spatial correlation, analogously to more common corrections for serial correlation, reveals higher standard errors than under usual OLS methods, so that such explanatory variables as education and a dummy variable for Asian growth are no longer statistically significant. As Chua (1993, p.31) notes, "The puzzle of the significant continent dummies is solved...This result rules out the notion that the continent dummies proxied for intrinsic cultural differences or political regime differences across continents." These papers, however, do not focus specifically on trade. They measure spatial proximity by simple dummy variables for common border or common regions, rather than using the full set of variables known to be useful in the gravity literature. As a result, the regional spillover effects found by Chua and Elliott could be due to many possible channels, whereas ours can be specifically identified with trade links."

11 Weinhold (1995) has recently extended the approach of these papers, to focus on differences in spatial dependence between industrialized and developing countries, making some use of the gravity equation. Moreno and Trehan (1996) argue that proximity matters for more reasons than just trade. 


\section{The Growth Equation}

Here we adopt the "conditional convergence" specification that has become common in the empirical literature on growth. While we consider a number of variants, our basic specification is given by equation (1) below. (See Mankiw, Romer, and Weil, 1992, for the theory and testing of this equation, but without the openness term.) The dependent variable is per capita GDP at the end of the sample, 1985. GDP per capita at the beginning of the sample period (1960) appears as an explanatory variable. ${ }^{12}$ The other explanatory variables are computed as averages over the sample periods, except for openness which is computed for 1985. The possible endogeneity of openness is the central focus of the paper.

$$
\begin{aligned}
& \log \left(Y / p o p_{8 j}\right)=\alpha+ \\
& \beta \log (T / Y)_{i}+\gamma \log (I / Y)_{i}+\delta \log (n)_{i}+\phi \log (S C H)_{i}+\lambda \log \left(Y / p o p_{60}\right)+u_{i} .
\end{aligned}
$$

where,

$Y$ is GDP;

pop is the country's working-age population (results were little affected when total population was used);

$T / Y$ is total trade (exports plus imports with all countries, not just those in the sample, even though these are a high percentage of world trade) as a share of GDP;

$I / Y$ is gross investment as a share of GDP;

${ }^{12}$ The hypothesis that countries are always in their Solow neoclassical growth steady-state equilibrium would predict that lagged income has no effect. This seems unlikely, however, as it should take countries a long time to converge to the long-run equilibrium. 
$n$ is the rate of growth of pop, plus an allowance of .05 for technological growth plus depreciation of the capital stock;

$S C H$ is an estimate of human capital investment based on schooling.

We measure $I / Y, n$, and $S C H$ as averages over the $1960-1985$ period, but $T / Y$ is for 1985 alone.

Our sample contains 100 to 123 countries, depending on availability of some variables.

Table 1 reports incomes for individual East Asian countries, and for the other countries aggregated by geographical area. In the quarter-century covered here, the East Asians went from an average income per worker that was 20 percent lower than that of the average of non-OECD countries, to a level 46 percent higher than theirs. ${ }^{13}$ Their investment shares and schooling levels were not only higher than those of the other non-OECD countries, but almost as high as those of the OECD countries. [Japan's were higher than those of other Western countries.] Certainly these factors are an important part of the East Asians' success. But might the trade share of the East Asian countries, which in Table 4 is on average higher than that for any of the other groups, also be part of the explanation?

The first column of Table 2 reports the results of a conventional OLS regression on Equation 1. The estimated coefficient on beginning-of-sample GDP is .7, indicating a $30 \%$ tendency toward conditional convergence over the 25 -year period. The coefficients on investment and schooling are highly significant, while the coefficient on the rate of growth of the labor force is not at all significant. The coefficient on openness, the chief focus of our interest, is significant at the 95 per cent level. Its point estimate suggests that for every 1 percent increase in trade as

${ }^{13}$ In income per capita, they went from a level that was slightly lower than the others, to a level more than twice as high. In other words, a large increase in the labor force participation rate was a major contributor to growth. 
a share of GDP, income per capita increases by .15 percent.

\section{The Gravity Equation for Determining Trade}

A standard gravity equation for bilateral trade between countries $i$ and $j$ is of the form:

$$
\begin{aligned}
\log \left(T_{i j} / Y_{j}\right)= & a+b_{1} \log \left(\text { Y }_{\text {Pop }}\right)+b_{2} \log \left(\text { Y }_{\text {Pop }}\right)+c_{1} \log \left(\text { Pop }_{j}\right)+c_{2} \log \left(\text { Pop }_{j}\right)+ \\
& d \log \left(\text { Dist }_{i j}\right)+f\left(\text { Adj }_{j j}\right)+g\left(L L_{i j}\right)+h_{1} \log \left(\text { Area }_{j}\right)+h_{2} \log \left(\text { Area }_{j}\right)+e_{i j}
\end{aligned}
$$

Because the aim is to construct a measure of country $i$ 's trade share that is exogenous, there is a problem in how to treat the incomes $Y_{j}$ of the trading partners. Ignoring the endogeneity of $Y_{j}$ does not seem optimal. In particular, if fitted values were constructed based on actual contemporaneous values of trading partner income, we might pick up spurious correlation due to common growth factors or linkages other than trade. One possible strategy is estimating a version of the equation that includes $Y_{j}$, with a coefficient constrained to unity. ${ }^{14}$ A second strategy is to drop trading partner incomes from the explanatory variables in the gravity model. This is not an entirely attractive solution either, because income is such an important variable in the gravity model; but the outcome of such estimation of the growth equation using purely "geographic" instrumental variables is reported anyway in column 2 of Table 2. A third strategy, our preferred one, is to substitute for $Y_{j}$ in the trade equation the fitted values of the partner income levels, based on the factor terms, $(I / Y)_{j}, n_{j}$, and $S C H_{j}$.

${ }^{14}$ Estimates such as many of those reported in Frankel (1996) support this constraint. Cyrus (1996) allows for the endogeneity of income in estimates of the gravity model, by using the factor accumulation variables as instruments. 
The predicted trade share for country $i$ is the sum of the predicted bilateral trade shares with all of its partners:

$$
\hat{(T / Y)_{i}}=\Sigma_{j}\left[\left(T_{i j} / Y_{i}\right)\right] .
$$

The sum is taken not just over the 63 countries for which we have bilateral trade data, but over 162 countries, virtually the entire world. (The growth regressions concentrate on a medium-sized data set of 123 countries, however, because these are the ones for which we have the necessary data on factor accumulation. An Appendix table A-11 lists them. ${ }^{15}$ )

It is a good idea to inspect the first-stage regressions, to make an assessment of the quality of the instruments. These are reported in Appendix Table A-4. In the full gravity model, the correlation between the fitted trade shares and actual trade shares is quite high. When the trading partners' GDPs are excluded, but populations and areas are included, the fitted trade shares still have a relatively high correlation with actual trade shares: 0.66 . The t-statistic in a regression of the actual trade share on the fitted share is 9.5 .

In Frankel and Romer (1995, Table 2), which reports the estimates of equation (2) in full, it is argued that for use in the growth equation, we are only interested in exogenous components of openness excluding the size of the domestic country. The argument is that splitting one country into two independent regions would raise the measured openness (trade/GDP) of each, even though it would at best leave unchanged the physical patterns of exchange of goods, and would thus at best leave unchanged the growth rates of each.' (More likely, trade between the

${ }^{15}$ China and Taiwan are included. (They were excluded from Frankel and Romer, 1995 [and from Table 2 of the January 1995 version of this paper], because we did not originally have the schooling data for these two countries.) 
two regions would fall, with an adverse affect on income per capita if the hypothesis is correct that appropriately-measured openness helps promote growth.) Holding constant for the area and population of the domestic country in a regression equation for actual openness, the t-statistic on the fitted trade share falls to 3.5. (If size variables are excluded from the beginning, the t-statistic on the "pure geography" model of openness is only 3.2.) Our preferred approach is to add domestic and foreign per capita GDPs back into equation (2), but only in the form of the fitted values of these variables in a conventional growth equation, ${ }^{16}$ where the exogenous variables are investment, population growth, and schooling. Under this approach, the t-statistic on the fitted trade share rises back to 6.6 [for the larger sample, and 4.8 for the smaller sample], even when controlling for area and population. In short, the geography and gravity models do supply useful instruments for openness.

Table 4 reports for the East Asian countries the "predicted trade share"17 alongside the first column, which repeats these countries' actual trade shares. In the second column the predicted trade share is computed using the pure geography approach, i.e., using only instrumental variables such as distance. In the third column, the predicted trade share includes also the effects of trading partners' factor accumulation. Hong Kong, Korea, Indonesia, Malaysia, Singapore, Taiwan, and Thailand have actual trade shares in excess of the geographically predicted trade

16 E.g., Mankiw, Romer and Weil (1992).

17 The predicted trade share is the fitted value in a regression of the actual trade share against the constructed trade share, the latter calculated as the sum (over the trading partners available in our data set) of the bilateral trade flows predicted from the geography equation. In other words, the numbers that were estimated on a reduced sample have been "blown up" to correspond to global trade. 
share. This might appear to suggest that deliberate outward-oriented policies, or an absence of the protectionist policies followed by the average of the 100 countries in the sample, contributed to their relatively high degree of openness. The other countries appear less open than the geographical factors predict. When the predicted trade share is constructed from the full gravity model, however, only two East Asian countries show an unpredictably high trade share: Singapore and Malaysia. Only these two show strong evidence of outward-oriented policies. Evidently countries like Korea, Taiwan, and Hong Kong come by their high trade shares in large part by virtue of the high rates of factor accumulation on the part of their neighbors (including each other). The same is true for East Asia in the aggregate. ${ }^{18}$

\section{The Simultaneous-Equation Estimates}

As explained above, two methods are used to construct the fitted trade share used in the instrumental variables growth regressions in Table 2: the pure geography approach and the gravity approach with partners' factor accumulations used in place of their GDPs. Under both approaches, the coefficient on the fitted trade share is statistically significant. ${ }^{19}$ Indeed the point estimate for the effect of openness is higher than it was in the OLS estimates. For every one

${ }^{18}$ To give the reader an idea why specific East Asian countries score high or low on predicted openness, the variables used in the geographical model, averaged for each country over its trading partners, are reported in Table 7. (These are weighted averages, using actual bilateral trade shares as weights.)

19 To allow for zero-values in bilateral trade data, we also tried using Tobit in the regression to construct the openness instrumental variable. The point estimates and significance levels are higher. [Those results are omitted here, but were reported in Table $2 \mathrm{~b}$ of CIDER Working Paper No. C95-050, U.C., Berkeley, also available as Pacific Basin Working Paper Series No. 95-03, Federal Reserve Bank of San Francisco, July 1995.] 
percent increase in trade as a share of GDP, income per capita is higher by an estimated .34 percent. The predicted effect of going from a closed economy to one where imports and exports sum to 200 percent of GDP (not as high as Hong Kong and Singapore), is to raise GDP by about 68 percent. ${ }^{20}$

These results suggest our central finding: simultaneity is not as serious a problem in appraising the effect of openness on growth as many have thought. A Hausman specification test fails to reject the hypothesis that the OLS and instrumental variables estimates are equal. To the extent that simultaneity is present, it seems to produce the opposite effect on the estimate from what has previously been feared.

\section{Implications for Trade-Led Growth Among Ten East Asian Countries}

The next step is to examine individual East Asian countries (particularly those with positive TFP growth residuals), and so see how much of their growth can be explained by the estimated effect of trade. We expressed the dependent variable (1960-1985 growth in GDP per capita) and the explanatory variables as deviations from the non-OECD world average. The explanatory variables, again, are: each country's openness, investment, population growth, schooling, and initial (1960) income per capita. Then we substituted these values into the estimated growth equation (the IV estimates) to see the role played by each factor in explaining

20 We noted earlier an argument that one should condition on country size, as measured by area and population, when observing the effects of openness on growth. In tests of this sort, the standard error of the coefficient on openness is increased, so that its t-statistic falls to 1.7 , though the point estimate is little affected. (When initial income per capita is excluded from the equation, openness remains statistically significant at the 95 percent level even when conditioning on country size.) These results are reported in Frankel and Romer (1995), Table 5. 
growth. The results are reported in Table 5. We see that openness explains a large amount of growth for Hong Kong and Singapore, and positive (though smaller) amounts also for Korea, Malaysia, and Taiwan. In the Philippines, where growth was lower than the world average, a low level of openness explains almost half this gap. Low openness detracted from the growth accomplished by China, Indonesia, Japan and Thailand. Of the other variables, investment and schooling are the dominant determinants in most of the countries.

Almost all countries have a large positive unexplained component, however, suggesting room for one's favorite stories about Confucianism, political stability, or government policy. The exceptions are China, where catch-up from a low initial GDP explains most of the growth, and Singapore. As in the Young (1992) results, the residual for Singapore is very small (actually substantially negative). In our case, however, openness, not factor accumulation, is the dominant explanation, apparently accounting for more of the growth miracle than investment and schooling combined. The Philippines is the other country, besides Singapore and China, where the residual is negative; but this is a matter of a partially unexplained poor growth performance, not a fullyexplained good performance. ${ }^{21}$

If openness was an important contributor to growth in many of these countries, was this the result of the accidents of geography and history, or might it have been the outcome of deliberate policies? Table 6 further breaks down the openness effect from Table $5 .^{22}$ In most

${ }^{21}$ The results are slightly different in the case of the pure geography instruments, reported in Table A-6. Openness explains a little less of growth in Hong Kong, Singapore and other countries, as compared to the case where output determinants are included among the regressors. But the explanatory power of openness is still large and significant.

${ }^{22}$ Appendix Tables A-7 and A-8 for the smaller sample. 
cases, the contribution of openness to growth is a contribution of trade as predicted by the gravity model; thus it cannot be attributed to policies. We see that for Korea, Hong Kong and Taiwan, the helpful effect of openness is fully predicted by the gravity model, leaving nothing as a residual. For Singapore and Malaysia, on the other hand, the contribution of predicted openness is smaller than the contribution of residual openness, presumably attributable to outward-oriented policies. In some of the cases where a level of openness less than the global average held back growth, a low level of residual openness was a more important component than was predicted openness. This describes China, Japan, the Philippines and Thailand. ${ }^{23}$

To summarize the results briefly, many of the explanations offered for East Asian growth indeed appear to play an important role: simple catch-up (particularly China, Indonesia, and Thailand), investment and education (especially Japan, Korea, Malaysia, Singapore, and Taiwan), and an unknown residual (especially Japan, which has a large positive residual, and the Philippines, where growth was much lower than one would predict). Openness plays a substantial role in many countries, especially Hong Kong and Singapore.

Several extensions of the research are desirable. In the results reported here, we do not constrain the coefficients $\mathrm{c}, \mathrm{g}$, and $\mathrm{h}$ to be the same for country $\mathrm{i}$ and country j, e.g., $g_{l}=g_{2}$, even though the dependent variable is the sum of both directions of trade. Eventually we will estimate a gravity equation for imports separately from exports; at that time it will be appropriate

${ }^{23}$ Again, the results are somewhat different when the instruments are restricted to geography variables. Now Hong Kong, Korea and Taiwan join Malaysia and Singapore, as countries where residual openness makes a larger contribution to growth than does predicted openness. But it seems likely that this residual openness is in part due to the rapid factor accumulation of neighbors, rather than to outward-oriented policies. 
to allow the coefficients on domestic and foreign variables to differ. Among other advantages, such an equation might allow us to distinguish whether the spillover effects from neighbors' growth come via exports, as traditionally assumed, or imports, as might be implied by some recent theory such as Grossman-Helpman (1991a, 1991b) ${ }^{24}$ Another possible extension for future research would be to attempt explicit tests that distinguish the importance of rapid growth among close trading partners from other determinants of trade.

Our current conclusion, however, is that the role played by openness in promoting growth turns out to stand up well to the simultaneity charges that have been leveled against it.

${ }^{24}$ Coe and Helpman (1993) test the theory, and find that TFP is affected not only by domestic R \& D, but also by $R \& D$ of those countries from whom the domestic country imports a lot. 


\section{References}

Barro, Robert, 1991, "Economic Growth in a Cross Section of Countries," Quarterly Journal of Economics, May.

Barro, Robert, and Xavier Sala-i-Martin, 1992, "Convergence," Journal of Political Economy.

Ben-David, Dan, 1993, "Equalizing Exchange: Trade Liberalization and Income Convergence," Quarterly Journal of Economics 108, August, 653-679.

Bhagwati, Jagdish, 1988, "Export Promoting Trade Strategy: Issues and Evidence," World Bank Research Observer, Jan. 3, no.1, 27-57.

Bradford, Colin, Jr., 1994, From Trade-Driven Growth to Growth-Driven Trade: Reappraising the East Asian Development Experience, Organisation for Economic Cooperation and Development, Paris.

Bradford, Colin, Jr, and Naomi Chakwin, 1993, "Alternative Explanation of the Trade-Output Correlation in the East Asian Economies," OECD Development Centre Technical Papers No. 87, Paris (August).

Coe, David, and Elhanan Helpman, 1993, "International R\&D Spillovers," National Bureau of Economic Research Working Paper No. 4444 (August).

Chua, Hak, 1993, "Regional Spillovers and Economic Growth," Harvard University, March.

Cyrus, Teresa, 1996, "A Note on the Endogeneity of Income in the Gravity Model of Bilateral Trade," chapter from draft Ph.D. dissertation, University of California, Berkeley, June.

DeLong, Bradford, and Lawrence Summers, 1991, "Equipment Investment and Economic Growth," Quarterly Journal of Economics 56, 2, 445-502.

Dollar, David, 1992, "Outward-oriented Developing Economies Really Do Grow More Rapidly: Evidence from 95 LDCs: 1976-1985," Economic Development and Cultural Change 40, 523-544.

Easterly, William, 1995, "Explaining Miracles: Growth Regressions Meet the Gang of Four," Fourth Annual NBER East Asian Seminar on Economics, San Francisco, June 1993. In Growth Theories in Light of the East Asian Experience edited by T. Ito and A. Krueger, University of Chicago Press, Chicago.

Easterly, William, Michael Kremer, Lant Pritchett, and Lawrence Summers, 1993, "Good Policy or Good Luck? Country Growth Performance and Temporary Shocks," National Bureau of Economic Research Working Paper No. 4474, September. Journal of Monetary Economics. 
Edwards, Sebastian, 1992, "Trade Orientation, Distortions, and Growth in Developing Countries," Journal of Development Economics, June 39, no.1, 31-57.

Edwards, Sebastian, 1993a, "Openness, Trade Liberalization, and Growth in Developing Countries," Journal of Economic Literature XXXI, September, 1358-1393.

Edwards, Sebastian, 1993b, "Trade Policy, Exchange Rates and Growth," National Bureau of Economic Research Working Paper No. 4511 (October).

Elliott, Graham, 1993, "Spatial Correlation and Cross Country Regressions," University of California, San Diego, July.

Esfahani, Hadi, 1991, "Exports, Imports, and Economic Growth in Semi-Industrialized Countries," Journal of Development Economics, January, 35, no.1, 93-116.

Eusufzai, Zaki, 1996, "Openness, Economic Growth, and Development: Some Further Results," Economic Development and Cultural Change 44, no. 2, January, 333-350.

Feder, Gershon, 1982, "On Exports and Economic Growth," Journal of Development Economics, Feb./Apr., 12, no. 1, 59-73.

Frankel, Jeffrey. 1993. "Is Japan Creating a Yen Bloc in East Asia and the Pacific?" in Regionalism and Rivalry: Japan and the U.S. in Pacific Asia, J. Frankel and M. Kahler, eds., Chicago: U. of Chicago Press.

Frankel, Jeffrey. 1996. Regional Trading Blocs, Institute for International Economics, Washington DC, forthcoming.

Frankel, Jeffrey, and David Romer, 1995, "Trade and Growth" University of California, Berkeley, November.

Frankel, Jeffrey, Ernesto Stein, and Shang-Jin Wei. 1993. "Trading Blocs: The Natural, the Unnatural, and the Super-Natural," the Sixth Inter American Seminar in Economics; NBER Working Paper No.4588, December.

Frankel, Jeffrey, and Shang-Jin Wei. 1994. "Is a Yen Bloc Emerging?" Fifth U.S-Korea Academic Symposium, September 7-9, at the University of California, Berkeley; in Economic Cooperation and Challenges in the Pacific, edited by Robert Rich, Korea Economic Institute of America: Washington, D.C.

Fukuda, Shin-ichi, and Hideki Toya, 1995, "Conditional Convergence in East Asian Countries: The Role of Exports for Economic Growth," Discussion Paper No. 57, Economic Research Institute, Economic Planning Agency, Tokyo (October 1993). In Growth Theories in Light of the East Asian Experience edited by T. Ito and A. Krueger, University of Chicago Press, Chicago. 
Grossman, Gene, and Elhanan Helpman, 1991a, Innovation and Growth in the Global Economy, MIT Press: Cambridge.

Grossman, Gene, and Elhanan Helpman, 1991b, "Trade, Knowledge Spillovers, and Growth," European Economic Review 35, no. 2-3, April, 517-526.

Harrison, Ann, 1995, "Openness and Growth: A Time-Series, Cross-Country Analysis for Developing Countries," NBER Working Paper No. 5221, August.

Helliwell, John, 1992, "International Growth Linkages: Evidence from Asia and the OECD," National Bureau of Economic Research Working Paper No. 4245 (December).

Helliwell, John, 1995, "Asian Economic Growth," in Wendy Dobson and Frank Flatters, eds., Pacific Trade and Investment: Options for the 90's (International and Development Studies Institute, Queen's University: Kingston, ONT.).

Helpman, Elhanan. 1987. "Imperfect Competition and International Trade: Evidence from Fourteen Industrial Countries," Journal of the Japanese and International Economies 1: 62-81.

Helpman, Elhanan. 1988, "Growth, Technological Progress, and Trade," National Bureau of Economic Research Reprint no. 1145.

Helpman, Elhanan and Paul Krugman. 1985. Market Structure and Foreign Trade, Cambridge, MIT Press.

Hutchison, Michael, and Nirvikar Singh, 1987, "Exports and Growth in Developing Economies: Identifying Externality Effects," Working Paper, University of California, Santa Cruz.

Hutchison, Michael, and Nirvikar Singh, 1992, "Exports, Non-Exports, and Externalities: A Granger Causality Approach," International Economic Journal 6, no.2, 79-94.

Jung, Woo, and Peyton Marshall, 1985, "Exports, Growth, and Causality in Developing Countries, " Journal of Development Economics 18, 1-12.

Kim, Jong-Il, and Lawrence Lau, 1994, "The Sources of Growth of the East Asian NewlyIndustrialized Countries," Journal of the Japanese and International Economies

Kohli, Inderjit, and Nirvikar Singh, 1989, "Exports and Growth: Critical Minimum Effort and Diminishing Returns," Journal of Development Economics, April, 30, no. 2, 391-400.

Krueger, Anne, 1978, Foreign Trade Regimes and Economic Development: Liberalization Attempts and Consequences, Ballinger for National Bureau of Economic Research.

Krueger, Anne, 1990, "Asian Trade and Growth Lessons," American Economic Review Papers 
and Proceedings 80, no. 2, May.

Krugman, Paul, 1994, "The Myth of Asia's Miracle," Foreign Affairs 73, no. 6, Nov./Dec., $62-78$.

Levine, Ross, and David Renelt, 1992, "A Sensitivity Analysis of Cross-Country Growth Regressions," American Economic Review 82, no. 4, 942-963.

Linneman, Hans. 1966. An Econometric Study of International Trade Flows, North-Holland, Amsterdam.

Mankiw, N. Gregory, David Romer and David Weil, 1992, "A Contribution to the Empirics of Economic Growth," Quarterly Journal of Economics 107, 407-437.

deMelo, Jaime, and Sherman Robinson, 1991, "Productivity and Externalities: Models of ExportLed Growth," PRE Working Papers, WPS 387, The World Bank.

Michaely, Michael, 1977, "Exports and Growth: An Empirical Investigation," Journal of Development Economics March, 4, no.1, 49-53.

Moreno, Ramon, and Bharat Trehan, 1996, "Location and Growth Spillovers: An Empirical Analysis," Federal Reserve Bank of San Francisco, March.

Pack, Howard, and John Page, 1994, "Accumulation, Exports, and Growth in the HighPerforming Asian Economies," Carnegie-Rochester Series on Public Policy 40, 199-236.

Pack, Howard, and Lawrence Westphal, 1986, "Industrial Strategy and Technological Change: Theory vs. Reality," Journal of Development Economics 22, 87-126.

Page, John, 1994, "The East Asian Miracle: Four Lessons for Development Policy," NBER Macroeconomics Annual, MIT Press: Cambridge, 219-280.

Rodrik, Dani, 1993, "Trade and Industrial Policy Reform in Developing Countries: A Review of Recent Theory and Evidence," National Bureau of Economic Research Working Paper no. 4417 (August).

Rodrik, Dani, 1994a, "King Kong Meets Godzilla: The World Bank and The East Asian Miracle," CEPR Discussion Paper No. 944, April.

Rodrik, Dani, 1994b, "Getting Interventions Right: How South Korea and Taiwan Grew Rich," 20th Panel Meeting of Economic Policy; NBER Working Paper No. 4964, December.

Romer, David, 1993, "Openness and Inflation: Theory and Evidence," Quarterly Journal of Economics, 108, no.4, November: 869-903. 
Romer, Paul, 1989, "What Determines the Rate of Growth and Technical Change?" World Bank Working Paper No. 279.

Quah, Danny, and James Rauch, 1990, "Openness and the Rate of Economic Growth," Working Paper, University of California, San Diego, Oct.

Sachs, Jeffrey, and Andrew Warner, 1995, "Economic Reform and the Process of Global Integration," Brookings Papers on Economic Activity 1, pp.1-95.

Sala-i-Martin, Xavier, 1991, "Comment," NBER Macroeconomics Annual 6, 368-378.

Sarel, Michael, 1995, "Growth in East Asia: What We Can and What We Cannot Infer From It," Productivity and Growth, Proceedings of a Conference, Palle Andersen, Jacqueline Dwyer and David Gruen, eds., Reserve Bank of Australia, 237-259.

Summers, Robert, and Alan Heston, 1988, "A New Set of International Comparison of Real Product and Price Levels: Estimates for 130 countries, 1950-85," Review of Income and Wealth 34, March, 1-26.

van den Berg, Hendrik, 1994, "Foreign Trade and Economic Growth: Time Series Evidence from Latin American," Journal of International Trade and Economic Development 3, no. 3, Nov., 249268.

Weinhold, Diana, 1995, "The Importance of Trade and Space for Economic Growth," Vanderbilt University, April.

World Bank, 1993, The East Asian Miracle: Economic Growth and Public Policy, Oxford University Press: New York.

Young, Alwyn, 1992, "A Tale of Two Cities: Productivity Growth in Hong Kong and Singapore," NBER Macroeconomics Annual 1992, National Bureau of Economic Research: Cambridge, MA.

Young, Alwyn, 1994, "Lessons from the East Asian NICS: A Contrarian View," European Economic Review Papers and Proceedings, May.

Young, Alwyn, 1995, "The Tyranny of Numbers: Confronting the Statistical Reality of the East Asian Growth Experience," Quarterly Journal of Economics 110, no. 3, August, 641-680. 
Table 1

\begin{tabular}{|c|c|c|c|c|c|}
\hline $\begin{array}{l}\text { country } \\
\text { or group }\end{array}$ & $\begin{array}{l}\text { per-worker } \\
\text { GDP, } 1985\end{array}$ & $\begin{array}{l}\text { per-worker } \\
\text { GDP, } 1960\end{array}$ & $\begin{array}{l}\text { average } \\
\text { investment } \\
\text { share }\end{array}$ & $\begin{array}{l}\text { growth of } \\
\text { working-age } \\
\text { population }\end{array}$ & $\begin{array}{l}\text { average } \\
\text { schooling }\end{array}$ \\
\hline China & 2166.00 & 1070.30 & 19.61 & 0.0222 & 0.0698 \\
\hline Hong Kong & 16447.00 & 4142.29 & 20.26 & 0.0304 & 0.0859 \\
\hline Indonesia & 4332.00 & 1645.70 & 14.64 & 0.0214 & 0.0361 \\
\hline Japan & 18820.00 & 4979.38 & 33.93 & 0.0122 & 0.119 \\
\hline S. Korea & 10361.00 & 2685.05 & 21.44 & 0.0278 & 0.105 \\
\hline Malaysia & 10458.00 & 4078.16 & 22.33 & 0.0315 & 0.0744 \\
\hline Philippines & 4229.00 & 2971.00 & 15.44 & 0.0251 & 0.103 \\
\hline Singapore & 17986.00 & 4911.34 & 30.65 & 0.0312 & 0.0953 \\
\hline Taiwan & 12701.00 & 3371.31 & 21.84 & 0.0288 & 0.109 \\
\hline Thailand & 4751.00 & 1878.00 & 16.90 & 0.0283 & 0.0427 \\
\hline East Asia & 10225.10 & 3173.25 & 21.71 & 0.0259 & 0.0840 \\
\hline $\begin{array}{l}\text { South } \\
\text { America }\end{array}$ & 9802.50 & 7666.50 & 18.33 & 0.0228 & 0.0703 \\
\hline $\begin{array}{l}\text { Central } \\
\text { America }\end{array}$ & 10245.85 & 6472.08 & 14.53 & 0.0237 & 0.0698 \\
\hline Africa & 3263.67 & 1986.81 & 10.11 & 0.0209 & 0.0229 \\
\hline OECD & 24363.75 & 13492.79 & 26.55 & 0.0115 & 0.0942 \\
\hline non-OECD & 7003.04 & 3974.23 & 14.14 & 0.0219 & 0.0483 \\
\hline world & 10390.50 & 5831.51 & 16.56 & 0.0199 & 0.0572 \\
\hline
\end{tabular}


Table 2: Determination of Real GDP per Capita in 1985

\begin{tabular}{|c|c|c|c|}
\hline & OLS & $\begin{array}{l}\text { IV } \\
\text { (geography) }\end{array}$ & $\begin{array}{c}\text { IV } \\
\text { (gravity) }\end{array}$ \\
\hline Constant & $\begin{array}{l}2.272 * * \\
(0.787)\end{array}$ & $\begin{array}{l}2.262^{*} \\
(0.789)\end{array}$ & $\begin{array}{l}2.159 * * \\
(0.817)\end{array}$ \\
\hline Openness $_{8 s}$ & $\begin{array}{l}0.00153^{*} \\
(0.00066)\end{array}$ & $\begin{array}{l}0.00171^{\dagger} \\
(0.00101)\end{array}$ & $\begin{array}{l}0.00344^{* *} \\
(0.00112)\end{array}$ \\
\hline $\ln \operatorname{lnv} v_{A v}$ & $\begin{array}{l}0.250^{* *} \\
(0.056)\end{array}$ & $\begin{array}{l}0.247^{* *} \\
(0.057)\end{array}$ & $\begin{array}{l}0.217 * * \\
(0.0598)\end{array}$ \\
\hline Ln Pop $G_{A v}$ & $\begin{array}{l}-0.255 \\
(0.226)\end{array}$ & $\begin{array}{l}-0.255 \\
(0.226)\end{array}$ & $\begin{array}{l}-0.257 \\
(0.233)\end{array}$ \\
\hline Ln School ${ }_{A v}$ & $\begin{array}{l}0.265^{* *} \\
(0.055)\end{array}$ & $\begin{array}{l}0.264^{* *} \\
(0.055)\end{array}$ & $\begin{array}{l}0.257^{* *} \\
(0.0570)\end{array}$ \\
\hline $\operatorname{Ln}(\mathrm{GDP} / \mathrm{Pop})_{60}$ & $\begin{array}{l}0.716^{* *} \\
(0.044)\end{array}$ & $\begin{array}{l}0.716^{* *} \\
(0.044)\end{array}$ & $\begin{array}{l}0.721 * * \\
(0.0455)\end{array}$ \\
\hline $\begin{array}{l}\text { No. Obs. } \\
\text { s.e.r. } \\
\mathbf{R}^{2} \\
\text { Adj. } \mathbf{R}^{2}\end{array}$ & $\begin{array}{l}123 \\
0.311 \\
0.919 \\
0.916\end{array}$ & $\begin{array}{l}123 \\
0.311 \\
0.919 \\
0.915\end{array}$ & $\begin{array}{l}123 \\
0.322 \\
0.913 \\
0.910\end{array}$ \\
\hline
\end{tabular}

$\dagger \quad$ significantly greater than zero at $90 \%$ level * significantly greater than zero at $95 \%$ level ** significantly greater than zero at $99 \%$ level

Note: The dependent variable is log GDP per worker in 1985. Averages are for the period 1960 to 1985. Inv is the average share of investment in GDP. Pop Growth is the average growth in the working-age population (plus 0.05, as in Mankiw-Romer-Weil, to account for technological progress and depreciation). School is the average secondary school enrollment ratio. In the IV regressions, predicted openness from the bilateral trade equations is used as an instrument for actual openness. Standard errors are reported in parentheses. 
Table 3: Bilateral Trade Equations

pure geography

gravity

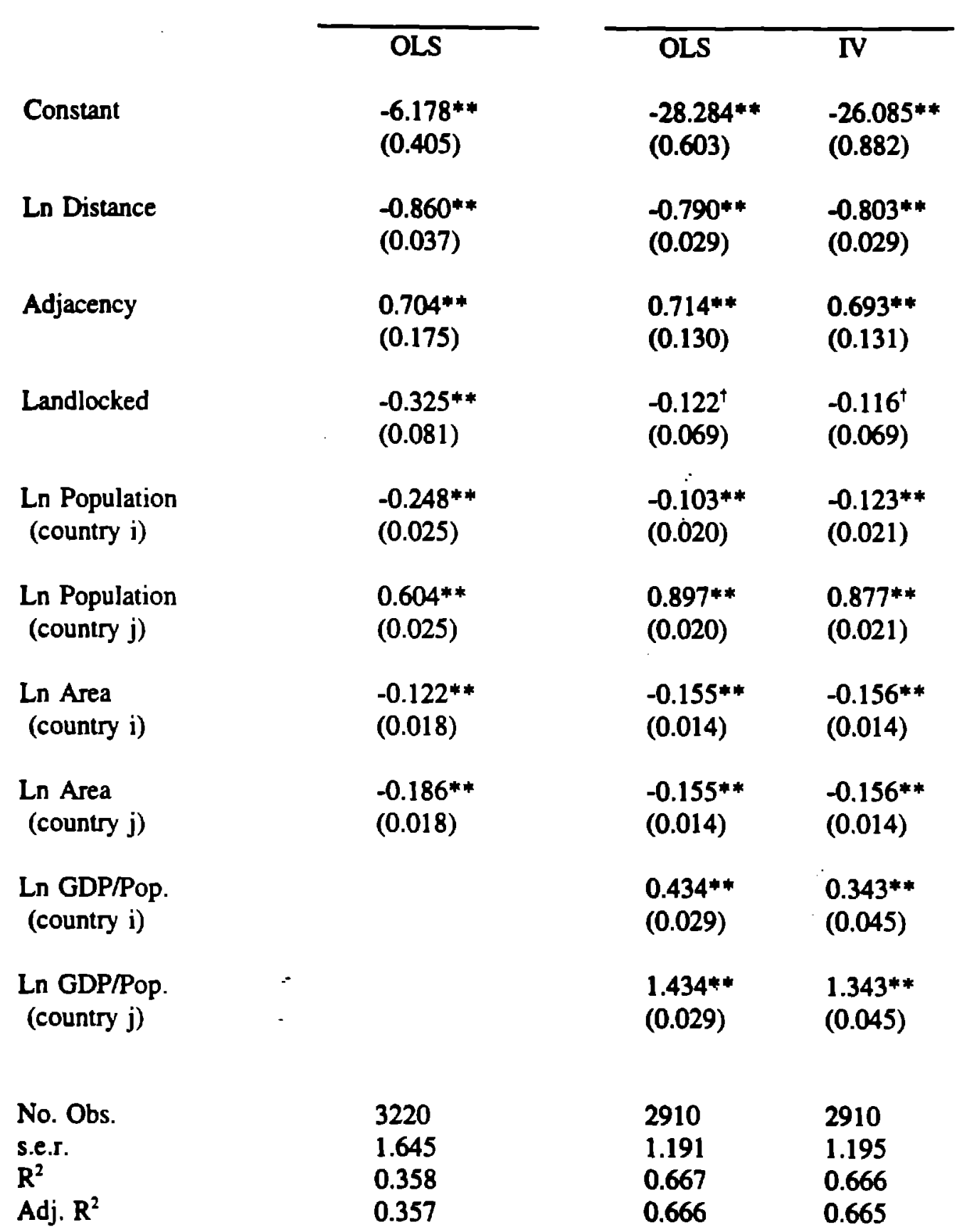

$\dagger \quad$ significantly greater than zero at $90 \%$ level

* significantly greater than zero at $95 \%$ level

** significantly greater than zero at $99 \%$ level

Note: The dependent variable is $\ln \left(T_{i j} / G D P_{i}\right)$ in 1985. Population indicates the working-age population in 1985. In the IV regression, fitted GDP per capita from a Mankiw-Romer-Weil-style factoraccumulation regression is used as an instrument for actual GDP per capita. Standard errors are reported in parentheses. 
Table 4

\begin{tabular}{|c|c|c|c|}
\hline country or group & $\begin{array}{l}\text { actual trade } \\
\text { share, } 1985\end{array}$ & $\begin{array}{l}\text { predicted } \\
\text { trade share } \\
\text { (geography) }\end{array}$ & $\begin{array}{l}\text { predicted } \\
\text { trade share } \\
\text { (gravity) }\end{array}$ \\
\hline China & 19.44 & 36.511 & 49.981 \\
\hline Hong Kong & 209.52 & 99.647 & 282.193 \\
\hline Indonesia & 42.66 & 39.017 & 52.703 \\
\hline Japan & 25.54 & 40.572 & 74.854 \\
\hline S. Korea & 67.86 & 58.270 & 115.555 \\
\hline Malaysia & 104.69 & 58.176 & 68.273 \\
\hline Philippines & 45.84 & 46.809 & 76.105 \\
\hline Singapore & 318.07 & 107.599 & 131.944 \\
\hline Taiwan & 94.62 & 63.563 & 152.115 \\
\hline Thailand & 51.20 & 49.005 & 62.227 \\
\hline East Asia & 97.944 & 59.917 & 106.595 \\
\hline South America & 47.090 & 50.577 & 53.871 \\
\hline Central America & 68.562 & 72.672 & 64.373 \\
\hline Africa & 63.826 & 63.547 & 54.189 \\
\hline OECD & 73.216 & 73.709 & 77.700 \\
\hline non-OECD & 65.504 & 65.384 & 64.417 \\
\hline world & 67.009 & 67.009 & 67.009 \\
\hline
\end{tabular}


Table 5: Contributions to Growth (Using Gravity-Version Predicted Trade Share)

\begin{tabular}{|c|c|c|c|c|c|c|c|c|}
\hline \multirow[b]{2}{*}{ country } & \multirow[b]{2}{*}{$\begin{array}{l}\text { growth of } \\
\text { per-worker } \\
\text { GDP } \\
1960-85\end{array}$} & \multirow[b]{2}{*}{$\begin{array}{l}\text { difference } \\
\text { in growth } \\
\text { above } \\
\text { world } \\
\text { average }\end{array}$} & \multicolumn{6}{|c|}{ contributions to difference in growth of various factors } \\
\hline & & & Openness & investment & $\begin{array}{l}\text { pop. } \\
\text { prowh }\end{array}$ & echooling & 1960 GDP & $\begin{array}{l}\text { unexplained } \\
\text { fuctors }\end{array}$ \\
\hline China & 0.70494 & 0.16753 & -0.16385 & 0.078424 & -0.010368 & 0.12767 & 0.34903 & -0.21338 \\
\hline Hong Kong & 1.37889 & 0.84148 & 0.49088 & 0.085541 & -0.038099 & 0.18105 & -0.028201 & 0.15031 \\
\hline Indonesia & 0.96786 & 0.43045 & -0.083868 & 0.015062 & -0.0073772 & -0.041849 & 0.22911 & 0.31938 \\
\hline Japan & 1.32961 & 0.79220 & -0.14284 & 0.19742 & 0.027817 & 0.26387 & -0.079506 & 0.52543 \\
\hline S. Korea & 1.35035 & 0.81294 & 0.002933 & 0.097832 & -0.029712 & 0.23284 & 0.092650 & 0.41639 \\
\hline Malaysia & 0.94172 & 0.40431 & 0.12979 & 0.10664 & -0.041358 & 0.14394 & -0.023852 & 0.089140 \\
\hline Philippines & 0.35307 & -0.18435 & -0.072915 & 0.026551 & -0.020558 & 0.22887 & 0.064441 & -0.41074 \\
\hline Singapore & 1.29805 & 0.76063 & 0.86478 & 0.17538 & -0.040558 & 0.20779 & -0.075671 & -0.37108 \\
\hline Taiwan & 1.32638 & 0.78897 & 0.095107 & 0.10180 & -0.032984 & 0.24231 & 0.029207 & 0.35352 \\
\hline Thailand & 0.92815 & 0.39073 & -0.054452 & 0.046227 & -0.031102 & 0.0013877 & 0.19230 & 0.23637 \\
\hline
\end{tabular}


Table 6: Contributions to Growth of Openness (Using Gravity-Version Predicted Trade Share)

\begin{tabular}{|c|c|c|c|c|}
\hline country & $\begin{array}{l}\text { difference } \\
\text { in growth }\end{array}$ & $\begin{array}{l}\text { contribution } \\
\text { of openness }\end{array}$ & $\begin{array}{l}\text { contribution } \\
\text { of predicted } \\
\text { openness }\end{array}$ & $\begin{array}{l}\text { contribution } \\
\text { of residual } \\
\text { openness }\end{array}$ \\
\hline China & 0.16753 & -0.16385 & -0.058651 & -0.10520 \\
\hline Hong Kong & 0.84148 & 0.49088 & 0.74120 & -0.25032 \\
\hline Indonesia & 0.43045 & -0.083868 & -0.049274 & -0.034594 \\
\hline Japan & 0.79220 & -0.14284 & 0.027023 & -0.16986 \\
\hline S. Korea & 0.81294 & 0.002933 & 0.16722 & -0.16428 \\
\hline Malaysia & 0.40431 & 0.12979 & 0.0043546 & 0.12544 \\
\hline Philippines & -0.18435 & -0.072915 & 0.031333 & -0.10425 \\
\hline Singapore & 0.76063 & 0.86478 & 0.22367 & 0.64111 \\
\hline Taiwan & 0.78897 & 0.095107 & 0.29315 & -0.19804 \\
\hline Thailand & 0.39073 & -0.054452 & -0.016469 & -0.037983 \\
\hline
\end{tabular}


Table 7: Weighted Average of Trading Partners' Data

\begin{tabular}{|c|c|c|c|c|c|c|}
\hline $\begin{array}{l}\text { country } \\
\text { or group }\end{array}$ & $\begin{array}{l}\text { per-worker } \\
\text { GDP, } 1985\end{array}$ & $\begin{array}{l}\text { total GDP, } \\
1985\end{array}$ & $\begin{array}{l}\text { number of } \\
\text { workers, } 1985\end{array}$ & $\begin{array}{l}\text { distance } \\
(\mathbf{k m})\end{array}$ & adjacency & $\begin{array}{l}\text { area } \\
\text { (sq mi) }\end{array}$ \\
\hline China & 20843.489 & 1.115E+09 & $4.791 E+07$ & 5112.412 & 0.215 & 7.333E+05 \\
\hline Hong Kong & 18262.329 & $1.506 \mathrm{E}+09$ & $1.969 E+08$ & 5863.527 & 0.252 & $1.864 E+06$ \\
\hline Indonesia & 22695.346 & $1.512 \mathrm{E}+09$ & $6.397 \mathrm{E}+07$ & 8112.013 & 0.006 & $9.388 E+05$ \\
\hline Japan & 22865.554 & $1.649 E+09$ & $1.007 \mathrm{E}+08$ & 7931.389 & 0.000 & $1.970 \mathrm{E}+06$ \\
\hline S. Korea & 24625.636 & $1.697 \mathrm{E}+09$ & $6.288 E+07$ & 7013.833 & 0.000 & $1.480 \mathrm{E}+06$ \\
\hline Malaysia & 19391.724 & $8.899 E+0 B$ & $4.647 \mathrm{E}+07$ & 5391.435 & 0.351 & $6.608 E+05$ \\
\hline Philippines & 23888.790 & $1.630 E+09$ & $7.952 E+07$ & 7730.283 & 0.000 & $1.481 \mathrm{E}+06$ \\
\hline Singapore & 19192.207 & $1.061 E+09$ & $6.422 \mathrm{E}+07$ & 6447.692 & 0.186 & $1.047 \mathrm{E}+06$ \\
\hline Taiwan & 26093.481 & $1.968 \mathrm{E}+09$ & $6.726 \mathrm{E}+07$ & 8131.020 & 0.000 & $1.750 \mathrm{E}+06$ \\
\hline Thailand & 21192.981 & $1.053 E+09$ & $6.872 E+07$ & 6429.923 & 0.074 & $9.349 E+05$ \\
\hline East Asia & 21905.154 & $1.408 \mathrm{E}+09$ & $7.985 \mathrm{E}+07$ & 6816.353 & 0.108 & $1.286 \mathrm{E}+06$ \\
\hline $\begin{array}{l}\text { South } \\
\text { America }\end{array}$ & 22452.352 & $1.411 E+09$ & $5.815 E+07$ & 7808.246 & 0.204 & $1.592 \mathrm{E}+06$ \\
\hline $\begin{array}{l}\text { Central } \\
\text { America }\end{array}$ & 30678.092 & $3.090 \mathrm{E}+09$ & $9.577 \mathrm{E}+07$ & 4516.473 & 0.736 & $2.757 \mathrm{E}+06$ \\
\hline Africa & 24810.585 & $9.918 \mathrm{E}+08$ & $4.247 E+07$ & 5789.293 & 0.014 & 7.799E+05 \\
\hline OECD & 24599.893 & $9.499 E+08$ & $4.139 \mathrm{E}+07$ & 3801.717 & 0.262 & 7.977E+05 \\
\hline non-OECD & 23087.701 & $1.218 \mathrm{E}+09$ & $5.652 E+07$ & 6235.259 & 0.116 & $1.122 E+06$ \\
\hline world & 23624.286 & $1.123 E+09$ & $5.115 E+07$ & 5371.744 & 0.168 & $1.007 \mathrm{E}+06$ \\
\hline
\end{tabular}


Table A-1: Gravity-Version Bilateral Trade Equations, Smaller Sample

\begin{tabular}{|c|c|c|}
\hline & OLS & IV \\
\hline Constant & $\begin{array}{l}-27.711^{* *} \\
(0.598)\end{array}$ & $\begin{array}{l}-28.994 * * \\
(0.800)\end{array}$ \\
\hline Ln Distance & $\begin{array}{l}-0.788 * * \\
(0.029)\end{array}$ & $\begin{array}{l}-0.780^{* *} \\
(0.029)\end{array}$ \\
\hline Adjacency & $\begin{array}{l}0.794^{* *} \\
(0.130)\end{array}$ & $\begin{array}{l}0.805^{* *} \\
(0.130)\end{array}$ \\
\hline Landlocked & $\begin{array}{l}-0.126 \dagger \\
(0.067)\end{array}$ & $\begin{array}{l}-0.130 \dagger \\
(0.067)\end{array}$ \\
\hline $\begin{array}{l}\text { Ln Population } \\
\text { (country i) }\end{array}$ & $\begin{array}{l}-0.082^{* *} \\
(0.021)\end{array}$ & $\begin{array}{l}-0.071^{* *} \\
(0.021)\end{array}$ \\
\hline $\begin{array}{l}\text { Ln Population } \\
\text { (country j) }\end{array}$ & $\begin{array}{l}0.918 * * \\
(0.021)\end{array}$ & $\begin{array}{l}0.929 * * \\
(0.021)\end{array}$ \\
\hline $\begin{array}{l}\text { Ln Area } \\
\text { (country i) }\end{array}$ & $\begin{array}{l}-0.183 * * \\
(0.014)\end{array}$ & $\begin{array}{l}-0.182^{* *} \\
(0.014)\end{array}$ \\
\hline $\begin{array}{l}\text { Ln Area } \\
\text { (country j) }\end{array}$ & $\begin{array}{l}-0.183^{* *} \\
(0.014)\end{array}$ & $\begin{array}{l}-0.182^{* *} \\
(0.014)\end{array}$ \\
\hline $\begin{array}{l}\text { Ln GDP/Pop. } \\
\text { (country i) }\end{array}$ & $\begin{array}{l}0.418^{* *} \\
(0.028)\end{array}$ & $\begin{array}{l}0.472^{* *} \\
(0.040)\end{array}$ \\
\hline $\begin{array}{l}\text { Ln GDP/Pop. } \\
\text { (country j) }\end{array}$ & $\begin{array}{l}1.418 * * \\
(0.028)\end{array}$ & $\begin{array}{l}1.472 * * \\
(0.040)\end{array}$ \\
\hline $\begin{array}{l}\text { No. Obs. } \\
\text { s.e.r. } \\
\mathrm{R}^{2} \\
\text { Adj. } \mathrm{R}^{2}\end{array}$ & $\begin{array}{l}2574 \\
1.123 \\
0.699 \\
0.698\end{array}$ & $\begin{array}{l}2574 \\
1.125 \\
0.699 \\
0.698\end{array}$ \\
\hline $\begin{array}{l}\text { significa } \\
\text { significa } \\
\text { significa }\end{array}$ & $\begin{array}{l}\text { an zero at } 95 \\
\text { an zero at } 99\end{array}$ & $\begin{array}{l}\text { level } \\
\text { level } \\
\text { level }\end{array}$ \\
\hline
\end{tabular}

Note: The dependent variable is $\ln \left(\mathrm{T}_{\mathrm{ij}} / \mathrm{GDP}_{\mathrm{i}}\right)$ in 1985 . Population indicates the working-age population in 1985. In the IV regression, fitted GDP per capita from a Mankiw-Romer-Weil-style factoraccumulation regression is used as an instrument for actual GDP per capita. The "smaller sample" includes the countries in Frankel-Romer plus China and Taiwan. Standard errors are reported in parentheses. 
Table A-2: Determination of Real GDP per Capita in 1985, Smaller Sample

OLS IV IV

(geography) (gravity)

\begin{tabular}{|c|c|c|c|}
\hline Constant & $\begin{array}{l}2.429 * * \\
(0.796)\end{array}$ & $\begin{array}{l}2.315^{* *} \\
(0.810)\end{array}$ & $\begin{array}{l}2.279 * * \\
(0.818)\end{array}$ \\
\hline Openness $_{85}$ & $\begin{array}{l}0.00165^{*} \\
(0.00072)\end{array}$ & $\begin{array}{l}0.00269^{*} \\
(0.00108)\end{array}$ & $\begin{array}{l}0.00301 * \\
(0.0012)\end{array}$ \\
\hline $\operatorname{Ln} \operatorname{Inv} v_{A v}$ & $\begin{array}{l}0.259^{* *} \\
(0.057)\end{array}$ & $\begin{array}{l}0.239 * * \\
(0.060)\end{array}$ & $\begin{array}{l}0.233 * * \\
(0.061)\end{array}$ \\
\hline $\operatorname{Ln}$ Pop $\mathrm{Gr}_{\mathrm{Av}}$ & $\begin{array}{l}-0.339 \\
(0.258)\end{array}$ & $\begin{array}{l}-0.353 \\
(0.261)\end{array}$ & $\begin{array}{l}-0.357 \\
(0.263)\end{array}$ \\
\hline Ln School $1_{\mathrm{Av}}$ & $\begin{array}{l}0.307^{* *} \\
(0.056)\end{array}$ & $\begin{array}{l}0.301 * * \\
(0.057)\end{array}$ & $\begin{array}{l}0.300^{* *} \\
(0.058)\end{array}$ \\
\hline $\operatorname{Ln}(\mathrm{GDP} / \mathrm{Pop})_{60}$ & $\begin{array}{l}0.683^{* *} \\
(0.050)\end{array}$ & $\begin{array}{l}0.689 * * \\
(0.050)\end{array}$ & $\begin{array}{l}0.691^{* *} \\
(0.051)\end{array}$ \\
\hline
\end{tabular}

$\begin{array}{llll}\text { No. Obs. } & 100 & 100 & 100 \\ \text { s.e.r. } & 0.287 & 0.290 & 0.292 \\ \mathrm{R}^{2} & 0.934 & 0.932 & 0.931 \\ \text { Adj. } \mathrm{R}^{2} & 0.930 & 0.929 & 0.928\end{array}$

$\dagger \quad$ significantly greater than zero at $90 \%$ level

* $\quad$ significantly greater than zero at $95 \%$ level

** significantly greater than zero at $99 \%$ level

Note: The dependent variable is log GDP per worker in 1985. Averages are for the period 1960 to 1985. Inv is the average share of investment in GDP. Pop Growth is the average growth in the working-age population (plus 0.05 , as in Mankiw-Romer-Weil, to account for technological progress and depreciation). School is the average secondary school enrollment ratio. In the IV regressions, predicted openness from the bilateral trade equations is used as an instrument for actual openness. Standard errors are reported in parentheses. 
Table A-3

\begin{tabular}{|c|c|c|c|}
\hline \multirow[b]{2}{*}{ country or group } & \multicolumn{3}{|c|}{ (Smaller Sample) } \\
\hline & $\begin{array}{l}\text { actual trade } \\
\text { share, } 1985\end{array}$ & $\begin{array}{l}\text { predicted } \\
\text { trade share } \\
\text { (geography) }\end{array}$ & $\begin{array}{l}\text { predicted } \\
\text { trade share } \\
\text { (gravity) }\end{array}$ \\
\hline China & 19.44 & 23.541 & 48.646 \\
\hline Hong Kong & 209.52 & 120.918 & 134.911 \\
\hline Indonesia & 42.66 & 27.406 & 46.926 \\
\hline Japan & 25.54 & 29.804 & 59.011 \\
\hline S. Korea & 67.86 & 57.100 & 77.073 \\
\hline Malaysia & 104.69 & 56.955 & 57.405 \\
\hline Philippines & 45.84 & 39.424 & 58.930 \\
\hline Singapore & 318.07 & 133.182 & 104.820 \\
\hline Taiwan & 94.62 & 65.265 & 84.895 \\
\hline Thailand & 51.20 & 42.811 & 52.188 \\
\hline East Asia & 97.944 & 59.641 & 72.480 \\
\hline South America & 47.090 & 37.777 & 49.111 \\
\hline Central America & 68.562 & 69.995 & 56.434 \\
\hline Africa & 63.826 & 58.339 & 48.493 \\
\hline OECD & 73.216 & 68.327 & 87.167 \\
\hline non-OECD & 65.504 & 59.409 & 54.095 \\
\hline world & 67.009 & 61.371 & 61.371 \\
\hline
\end{tabular}


Table A-4: First-Stage Regressions

$\begin{array}{lllll}\text { Constant } & \begin{array}{l}30.797^{* *} \\ (4.867)\end{array} & \begin{array}{l}153.868^{* *} \\ (31.431)\end{array} & \begin{array}{l}43.113^{* *} \\ (4.038)\end{array} & \begin{array}{l}155.866^{* *} \\ (19.566)\end{array} \\ \begin{array}{l}\text { Constructed Openness } \\ \text { (Geography) }\end{array} & \begin{array}{l}1.831^{* *} \\ (0.192)\end{array} & \begin{array}{l}0.928^{* *} \\ (0.292)\end{array} & & \\ \text { Constructed Openness } & & & & \\ \quad \text { (Gravity) } & & 0.869^{* *} & 0.692^{* *} \\ & & & (0.094) & (0.105) \\ \text { Ln Population } & & & \\ & & -4.010 & & -10.744^{* *} \\ & & (2.424) & & (2.213) \\ \text { Ln Area } & & -6.439 * * & & -1.790 \\ & & (2.291) & & (2.129) \\ & & & & \\ \text { No. Obs. } & & & & 123 \\ \text { s.e.r. } & 123 & 123 & 123 & 28.593 \\ R^{2} & 33.822 & 32.059 & 34.330 & 0.599 \\ \text { Adj. } R^{2} & 0.430 & 0.496 & 0.412 & 0.589 \\ & 0.425 & 0.483 & 0.408 & \end{array}$

$\dagger \quad$ significantly greater than zero at $90 \%$ level

$* \quad$ significantly greater than zero at $95 \%$ level

** significantly greater than zero at $99 \%$ level

Note: The dependent variable is actual openness (exports plus imports as a percentage of GDP) in 1985. Standard errors are reported in parentheses. 
Table A-5: Contributions to Growth (Using Gravity-Version Predicted Trade Share), Smaller Sample

\begin{tabular}{|c|c|c|c|c|c|c|c|c|}
\hline \multirow[b]{2}{*}{ country } & \multirow[b]{2}{*}{$\begin{array}{l}\text { growth of } \\
\text { per-worker } \\
\text { GDP } \\
1960-85\end{array}$} & \multirow[b]{2}{*}{$\begin{array}{l}\text { difference } \\
\text { in growth } \\
\text { above } \\
\text { non-OECD } \\
\text { average }\end{array}$} & \multicolumn{6}{|c|}{ contributions to difference in growth of various factors } \\
\hline & & & openness & investment & $\begin{array}{l}\text { pop. } \\
\text { growth }\end{array}$ & schooling & 1960 GDP & $\begin{array}{l}\text { unexplained } \\
\text { factors }\end{array}$ \\
\hline China & 0.70494 & 0.23915 & -0.12193 & 0.14293 & 0.001420 & 0.23438 & 0.28160 & -0.31111 \\
\hline Hong Kong & 1.37889 & 0.91310 & 0.45063 & 0.15059 & -0.037073 & 0.29657 & -0.13686 & 0.17740 \\
\hline Indonesia & 0.96786 & 0.50207 & -0.051986 & 0.074751 & 0.005571 & 0.036885 & 0.14857 & 0.27643 \\
\hline Japan & 1.32961 & 0.86382 & -0.10355 & 0.27098 & 0.054424 & 0.39307 & -0.19378 & 0.43083 \\
\hline S. Korea & 1.35035 & 0.88456 & 0.023921 & 0.16382 & -0.025432 & 0.35691 & -0.002805 & 0.35629 \\
\hline Malaysia & 0.94172 & 0.47593 & 0.13486 & 0.17330 & -0.041597 & 0.25334 & -0.13204 & 0.076214 \\
\hline Philippines & 0.35307 & -0.11272 & -0.042407 & 0.087114 & -0.012725 & 0.35229 & -0.034097 & -0.47475 \\
\hline Singapore & 1.29805 & 0.83226 & 0.77760 & 0.24726 & -0.040487 & 0.32772 & -0.18952 & -0.30218 \\
\hline Taiwan & 1.32638 & 0.86059 & 0.10453 & 0.16809 & -0.029974 & 0.36795 & -0.073183 & 0.31132 \\
\hline Thailand & 0.92815 & 0.46236 & -0.026262 & 0.10829 & -0.027362 & 0.087257 & 0.10774 & 0.20084 \\
\hline
\end{tabular}


Table A-6: Contributions to Growth (Using Geography-Version Predicted Trade Share), Larger Sample contributions to difference in growth of various factors

\begin{tabular}{|c|c|c|c|c|c|c|c|c|}
\hline \multirow[b]{2}{*}{ country } & \multirow[b]{2}{*}{$\begin{array}{l}\text { growth of } \\
\text { per-worker } \\
\text { GDP } \\
1960-85\end{array}$} & \multirow[b]{2}{*}{$\begin{array}{l}\text { difference } \\
\text { in growth } \\
\text { above } \\
\text { non-OECD } \\
\text { average }\end{array}$} & \\
\hline & & & openness & investment & $\begin{array}{l}\text { pop. } \\
\text { growth }\end{array}$ & schooling & 1960 GDP & $\begin{array}{l}\text { unexplained } \\
\text { factors }\end{array}$ \\
\hline China & 0.70494 & 0.19708 & -0.078579 & 0.12855 & -0.002470 & 0.18009 & 0.27477 & -0.31643 \\
\hline Hong Kong & 1.37889 & 0.87103 & 0.24567 & 0.13666 & -0.030012 & 0.23487 & -0.10890 & 0.38158 \\
\hline Indonesia & 0.96786 & 0.46000 & -0.038968 & 0.056336 & 0.000500 & 0.006106 & 0.15280 & 0.27208 \\
\hline Japan & 1.32961 & 0.82175 & -0.068173 & 0.26417 & 0.035454 & 0.31988 & -0.16108 & 0.42035 \\
\hline S. Korea & 1.35035 & 0.84249 & 0.0040197 & 0.15067 & -0.021682 & 0.28804 & 0.014011 & 0.39628 \\
\hline Malaysia & 0.94172 & 0.43386 & 0.066847 & 0.16071 & -0.033249 & 0.19679 & -0.10448 & 0.13609 \\
\hline Philippines & 0.35307 & -0.15479 & -0.033544 & 0.069430 & -0.012590 & 0.28396 & -0.014679 & -0.45852 \\
\hline Singapore & 1.29805 & 0.79019 & 0.43085 & 0.23906 & -0.032454 & 0.26232 & -0.15718 & 0.036450 \\
\hline Taiwan & 1.32638 & 0.81852 & 0.049669 & 0.15520 & -0.024932 & 0.29776 & -0.050515 & 0.38019 \\
\hline Thailand & 0.92815 & 0.42029 & -0.024400 & 0.091855 & -0.023063 & 0.050482 & 0.11536 & 0.19890 \\
\hline
\end{tabular}


Table A-7: Contributions to Growth (Using Geography-Version Predicted Trade Share), Smaller Sample

\begin{tabular}{|c|c|c|c|c|c|c|c|c|}
\hline \multirow[b]{2}{*}{ country } & \multirow[b]{2}{*}{$\begin{array}{l}\text { growth of } \\
\text { per-worker } \\
\text { GDP } \\
1960-85\end{array}$} & \multirow[b]{2}{*}{$\begin{array}{l}\text { difference } \\
\text { in growth } \\
\text { above } \\
\text { world } \\
\text { average }\end{array}$} & \multicolumn{6}{|c|}{ contributions to difference in growth of various factors } \\
\hline & & & openness & investment & $\begin{array}{l}\text { pop. } \\
\text { growth }\end{array}$ & schooling & 1960 GDP & $\begin{array}{l}\text { unexplained } \\
\text { factors }\end{array}$ \\
\hline China & 0.70494 & 0.23915 & -0.10897 & 0.14660 & 0.001403 & 0.23568 & 0.28321 & -0.33027 \\
\hline Hong Kong & 1.37889 & 0.91310 & 0.40274 & 0.15445 & -0.036640 & 0.29821 & -0.13765 & 0.22049 \\
\hline Indonesia & 0.96786 & 0.50207 & -0.046461 & 0.076667 & 0.005506 & 0.037089 & 0.14942 & 0.26835 \\
\hline Japan & 1.32961 & 0.86382 & -0.092549 & 0.27792 & 0.053788 & 0.39524 & -0.19489 & 0.41280 \\
\hline S. Korea & 1.35035 & 0.88456 & 0.021379 & 0.16802 & -0.025135 & 0.35889 & -0.002821 & 0.35273 \\
\hline Malaysia & 0.94172 & 0.47593 & 0.12053 & 0.17774 & -0.041112 & 0.25474 & -0.13280 & 0.085329 \\
\hline Philippines & 0.35307 & -0.11272 & -0.037900 & 0.089347 & -0.012576 & 0.35424 & -0.034293 & -0.48304 \\
\hline Singapore & 1.29805 & 0.83226 & 0.69496 & 0.25360 & -0.040014 & 0.32954 & -0.19061 & -0.22672 \\
\hline Taiwan & 1.32638 & 0.86059 & 0.093418 & 0.17240 & -0.029624 & 0.36999 & -0.073602 & 0.31651 \\
\hline Thailand & 0.92815 & 0.46236 & -0.023471 & 0.11106 & -0.027042 & 0.087741 & 0.10835 & 0.19421 \\
\hline
\end{tabular}


Table A-8: Contributions to Growth of Openness (Using Gravity-Version Predicted Trade Share), Smaller Sample

\begin{tabular}{|c|c|c|c|c|}
\hline country & $\begin{array}{l}\text { difference } \\
\text { in growth }\end{array}$ & $\begin{array}{l}\text { contribution } \\
\text { of openness }\end{array}$ & $\begin{array}{l}\text { contribution } \\
\text { of predicted } \\
\text { openness }\end{array}$ & $\begin{array}{l}\text { contribution } \\
\text { of residual } \\
\text { openness }\end{array}$ \\
\hline China & 0.23915 & -0.12193 & -0.033954 & -0.087974 \\
\hline Hong Kong & 0.91310 & 0.45063 & 0.22589 & 0.22473 \\
\hline Indonesia & 0.50207 & -0.051986 & -0.039137 & -0.012849 \\
\hline Japan & 0.86382 & -0.10355 & -0.002734 & -0.10082 \\
\hline S. Korea & 0.88456 & 0.023921 & 0.051672 & -0.027751 \\
\hline Malaysia & 0.47593 & 0.13486 & -0.007572 & 0.14243 \\
\hline Philippines & -0.11272 & -0.042407 & -0.002978 & -0.039429 \\
\hline Singapore & 0.83226 & 0.77760 & 0.13525 & 0.64235 \\
\hline Taiwan & 0.86059 & 0.10453 & 0.075233 & 0.029294 \\
\hline Thailand & 0.46236 & -0.026262 & -0.023285 & -0.002977 \\
\hline
\end{tabular}


Table A-9: Contributions to Growth of Openness (Using Geography-Version Predicted Trade Share), Larger Sample

\begin{tabular}{|c|c|c|c|c|}
\hline country & $\begin{array}{l}\text { difference } \\
\text { in growth }\end{array}$ & $\begin{array}{l}\text { contribution } \\
\text { of openness }\end{array}$ & $\begin{array}{l}\text { contribution } \\
\text { of predicted } \\
\text { openness }\end{array}$ & $\begin{array}{l}\text { contribution } \\
\text { of residual } \\
\text { openness }\end{array}$ \\
\hline China & 0.19708 & -0.078579 & -0.049457 & -0.029122 \\
\hline Hong Kong & 0.87103 & 0.24567 & 0.058244 & 0.18743 \\
\hline Indonesia & 0.46000 & -0.038968 & -0.045183 & 0.0062141 \\
\hline Japan & 0.82175 & -0.068173 & -0.042530 & -0.025643 \\
\hline S. Korea & 0.84249 & 0.004020 & -0.012340 & 0.016359 \\
\hline Malaysia & 0.43386 & 0.066847 & -0.012500 & 0.079347 \\
\hline Philippines & -0.15479 & -0.033544 & -0.031890 & -0.0016537 \\
\hline Singapore & 0.79019 & 0.43085 & 0.071809 & 0.35904 \\
\hline Taiwan & 0.81852 & 0.049669 & -0.003310 & 0.052979 \\
\hline Thailand & 0.42029 & -0.024400 & -0.028144 & 0.0037436 \\
\hline
\end{tabular}


Table A-10: Contributions to Growth of Openness (Using Geography-Version Predicted Trade Share), Smaller Sample

\begin{tabular}{|c|c|c|c|c|}
\hline country & $\begin{array}{l}\text { difference } \\
\text { in growth }\end{array}$ & $\begin{array}{l}\text { contribution } \\
\text { of openness }\end{array}$ & $\begin{array}{l}\text { contribution } \\
\text { of predicted } \\
\text { openness }\end{array}$ & $\begin{array}{l}\text { contribution } \\
\text { of residual } \\
\text { openness }\end{array}$ \\
\hline China & 0.23915 & -0.10897 & -0.097930 & -0.011041 \\
\hline Hong Kong & 0.91310 & 0.40274 & 0.16421 & 0.23852 \\
\hline Indonesia & 0.50207 & -0.046461 & -0.087526 & 0.041064 \\
\hline Japan & 0.86382 & -0.092549 & -0.081069 & -0.011480 \\
\hline S. Korea & 0.88456 & 0.021379 & -0.007587 & 0.028966 \\
\hline Malaysia & 0.47593 & 0.12053 & -0.007977 & 0.12850 \\
\hline Philippines & -0.11272 & -0.037900 & -0.055172 & 0.017272 \\
\hline Singapore & 0.83226 & 0.69496 & 0.19723 & 0.49773 \\
\hline Taiwan & 0.86059 & 0.093418 & 0.014392 & 0.079027 \\
\hline Thailand & 0.46236 & -0.023471 & -0.046054 & 0.022583 \\
\hline
\end{tabular}


Table A-11: Countries

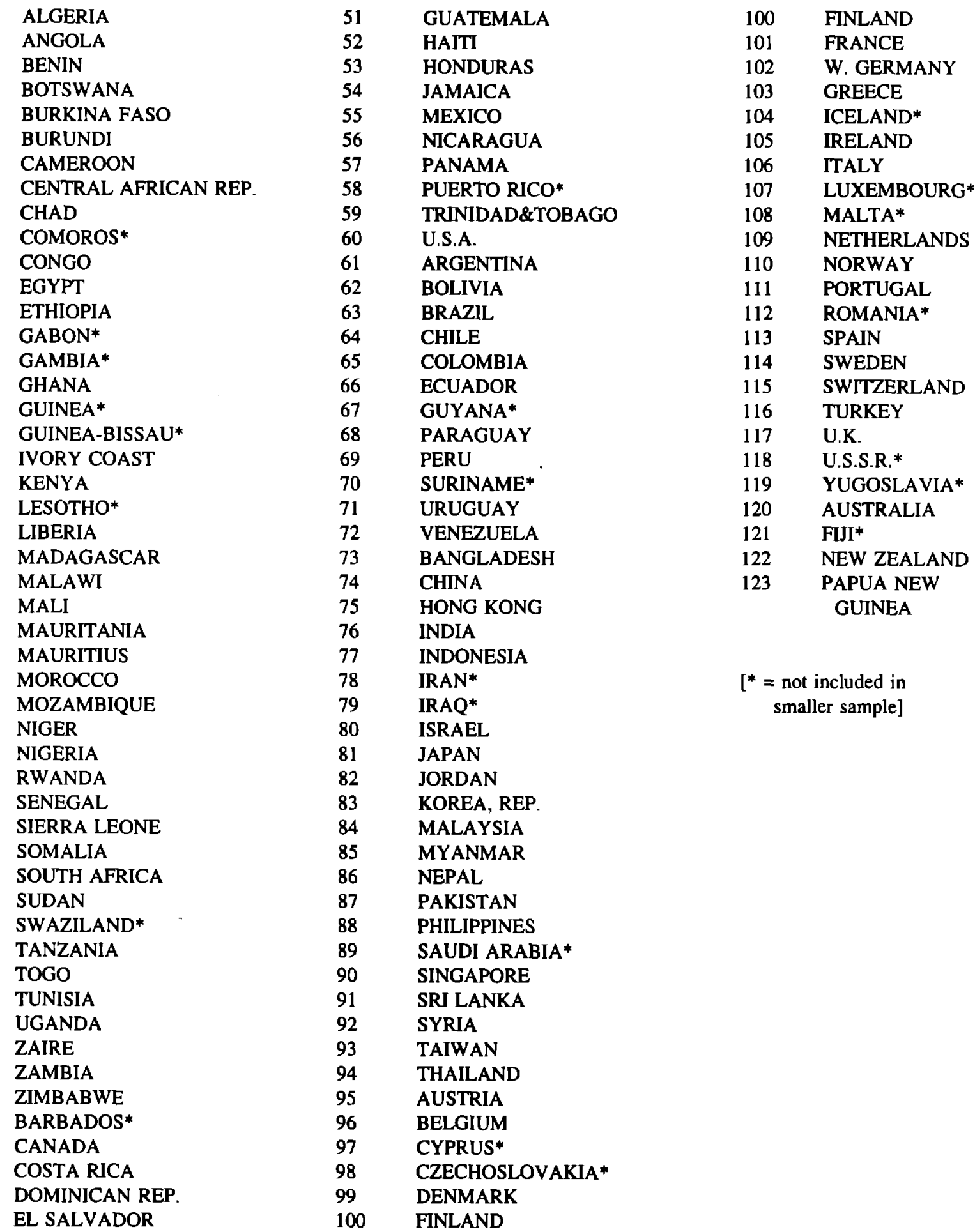

Note: The full bilateral trade dataset includes data for 63 countries. To obtain the predicted trade shares, subsets of the bilateral trade dataset were used, corresponding to the countries in various samples (geography and gravity versions; small and large samples). The geography version used 62 of the 63 countries; the large-sample (123-country) gravity version used 59 countries, while the small-sample (100-country) version used 55. 